\title{
Fetal Hemoglobin Levels and Splenic Function in Sickle-Cell
} Disease

\begin{tabular}{|l|l|l|}
\hline S. & Sinasi & Özsoylu \\
\hline
\end{tabular}

Ankara

Sinasi Özsoylu, MD, Professor of Pediatrics and Pediatric Hematologist, Hacettepe University, Faculty of Medicine, Department of Pediatrics, Hematology Unit and Hacettepe Children's Hospital, Ankara (Turkey)

A. Al-Awamy et al. [1] inclined to relate the absence of priapism in Saudi sickle-cell anemia patients to the high $\mathrm{Hb}$ F levels of their patients in a recent communication. This conclusion was supported by comparing their patients' findings with those of Jamaican patients with sickle cell anemia. Although $\mathrm{Hb} F$ levels in

Turkish sickle cell anemia patients are also higher (mean 11.5\%; range 1.7-36\%) compared to the Jamaican patients, we could not show any correlation between its concentration and hemaglobin, hematocrit levels, reticulocyte and normoblast counts in our patients [2]. Since $\mathrm{Hb} F$ levels of the authors' patients

Table I. Splenic size, Hb F levels and scanning results in patients with sickle cell disease Age

Sex

Spleen, $\mathrm{cm}$

$\mathrm{Hb}$ F, \%

Splenic scanning

Patients with Hb SS 
8

M

9

8

M

10

8

M

11

13

M

12

14

F

13

20

M

Mean

13.975

Patients with Hb S-ß-thalassemia

2.5

8

9

15

15

69

$7 \quad 10$

M F M F F M F

3

14

N

3

19 
$\mathrm{NU}=$ No uptake; $\mathrm{D}=$ decreased; $\mathrm{N}$ = normal; $\mathrm{NP}=$ not palpable.

Fetal Hemoglobin Levels and Splenic Function in Sickle-Cell Disease 241

ranged between 10.3 and 29\%, I would like to learn whether they have found any correlation between its level and the parameters we looked for.

The authors also mentioned that the elevated $\mathrm{Hb} F$ levels of their patients played an important role in preserving the splenic function in Saudi sickle cell anemia patients [3]. We could not find any correlation between $\mathrm{Hb} F$ levels and splenic functions in our sickle cell anemia and sickle cell-ß-thalassemia patients by "Tc-sulfur colloid uptake [4] (table I). All of these patients, with one exception (who had sickle cell-/?-thalassemia), had a Hb S, F, A2 pattern [5].

In general, splenic functions of our patients seemed also to be better preserved compared to American sickle cell anemia patients. But, despite a very slight difference in the mean $\mathrm{Hb} F$ values between our sickle cell anemia and sickle cell-ß-thalassemia (13.97 vs. 15.5\%) patients, the defect in "Tc-sulfur colloid uptake was very marked, being 85 and 28.6\%, respectively. Because of the above reasons, we believe that the importance of $\mathrm{Hb} \mathrm{F}$ alone in the discrimination of clinical and laboratory findings in sickle cell disease should be reevaluated in different populations.

References

Al-Awamy, B.; Taha, S.A.; Naeem, M.A.: Priapism in association with sickle cell anemia in Saudi Arabia. Acta haemat. 73: 181-182(1985).

Özsoylu, S.; Altinöz, N.: Sickle cell anemia in Turkey. Evaluation of 97 cases (with parents' findings). Scand. J. Haematol. 19: 85-92(1977).

Al-Awamy, B.; Wilson, W.A.; Pearson, H.A.: Splenic function in sickle cell disease in the Eastern province of Saudi Arabia. J. Pediat. 104: 714-717(1984).

Özsoylu, S.: Splenic function in sickle cell disease. J. Pediat. 106: 530-531(1985). 
Özsoylu, S.; Altinöz, N.; Laleli, Y.: Splenic functions in non-Negro patients with sickle cell anemia and sickle cell beta thal-assemia. Turk. J. Pediat. 21: 36-45 (1979). 